\title{
Academic and Administrative Attitude of Prospective Teachers Towards Teaching Profession
}

\author{
Dr. Albert S. Tirkey* \\ *Assistant Professor, Don Bosco College of Teacher Education, Tura (Meghalaya)
}

\begin{abstract}
Education seeks to develop the innate inner capacities of man. The ultimate goal of education is to prepare the students to be responsible and mentally healthy person to live on this earth. In order to achieve this, students are to be molded only by making them experience the significance of values in the school itself. In most of the cases education takes place under the guidance of teachers. Teachers are the biggest influencers in a student's life. Their personality and attitudes contribute to a great extend in students learning. In this respect, determining the attitude of prospective teachers towards teaching profession is of great importance. The main objectives of this paper are to test: academic attitude of prospective teachers towards teaching profession; and administrative attitude of prospective teachers towards teaching profession. Tool used for the study was 'attitude scale towards teaching', developed by Dr. (Mrs.) Ummen Kulsum. In order to analyze the data, $Z$-score in terms of standard deviations from the mean was used. The study was delimited to West Garo Hills District of Meghalaya.
\end{abstract}

Keywords:- Attitude, Academic, Administrative, Teaching Profession.

\section{INTRODUCTION}

The objective of education is to develop the innate inner capacities of man. Through education it is an attempt to give an individual some desirable knowledge, understanding, skills, interest, attitudes and critical thinking. That is, he acquires knowledge of history, geography, arithmetic, languages and sciences. As an individual in the society, he has to think critically about various issues in life and take resolutions about them being free from bias and prejudices, superstitions and blind beliefs. Aristotle has rightly defined education as: "Education is the process of training man to fulfill his aim by exercising all the faculties to the fullest extent as a member of society". So, the aim of education is to be the flourishing the human on this earth. According to a UNESCO's study, "the physical, intellectual, emotional and ethical integration of the individual into a complete man/woman is the fundamental aim of education". Hence, the object of educations should be to form children into human persons who are committed to work for the creation of human communities of love, companionship, liberation, equity, harmony etc. In order to achieve this, students are to be molded only by making them experience the significance of these values in the school itself.
Education frequently materialized under the guidance of teachers. They have always been the biggest influencers in a student's life. Their beliefs, practices and attitudes are key for realizing and improving educational processes. Brown (2001) has rightly stated that; the roles teachers play and the styles they develop will merge to give them tools for creating a classroom climate that is positive, stimulating, and energizing. Highly motivated teachers, and having positive attitude towards their teaching profession can establish good relationship in the classroom, motivate students, create positive energy, facilitate the process of learning, provide advice and counsel when students seek it, all these enhance the quality of teaching. Today's generation cannot just be told what they must do, but rather they need to be inspired by the wisdom of teachers; to decide for themselves on how they would like to use education as a tool for themselves.

Development of positive attitude towards profession helps in developing creative thinking and motivating students (Celikoz \& Cetin; 2004). And it has been identified that teacher's attitudes, either positive or negative has a significant influence to teaching and learning. The kind of attitude owned by the teacher influence the quality of the work achieved in teaching. Therefore, many researchers have set off to determine teachers' attitudes towards their teaching profession. As defined by Anastasi (1957) that, attitude as a complex mental state involving beliefs and a tendency to react in a way towards a designed class of stimuli. Hence, it can be stated that teachers attitude towards their teaching profession is important in the process of teaching learning, because, the progressive world has added new dimension to this profession, which requires specified competencies and right attitude from the teachers. Since, a positive classroom climate starts with the teacher's attitude towards his profession and ends with the student's attitude.

\section{SIGNIFICANCE OF THE STUDY}

As the mental health development is molded in a specific environment in which he/she is reared, is important. The world is progressing day by day and education is the only key to match the pace of progressing world. There is an explosion of knowledge, increasing every day with an unprecedented speed. Information has been revolutionized. In terms of the developing knowledge, various types of information are now available for an individual to know. Where, the standard of students' performance remains at the top concern for parents and educators. Therefore, Prospective teacher's attitude towards teaching plays an important role in his/her ability to transfer 
teaching skills in real classroom situation. Because, A teacher with right attitude puts students' learning as the supreme goal and mixes and matches all the available tools and techniques to suit the teaching - learning process distinctive to a given subject or topic or class. In this respect, determining the attitude of student teachers towards teaching profession is of great importance. The teacher's attitude and his or her perspective towards life, to students, and teaching have a great deal to do with how his pupil will be. Attitude of prospective teachers begins during their passage of becoming teachers in their schools, colleges, university and more specifically in teacher training institutes.

Hence, present study is an attempt to study the academic and administrative attitude of the prospective teachers towards teaching profession.

Delimitation: Delimited to West Garo Hills District of Meghalaya, India.

Framework for the analysis

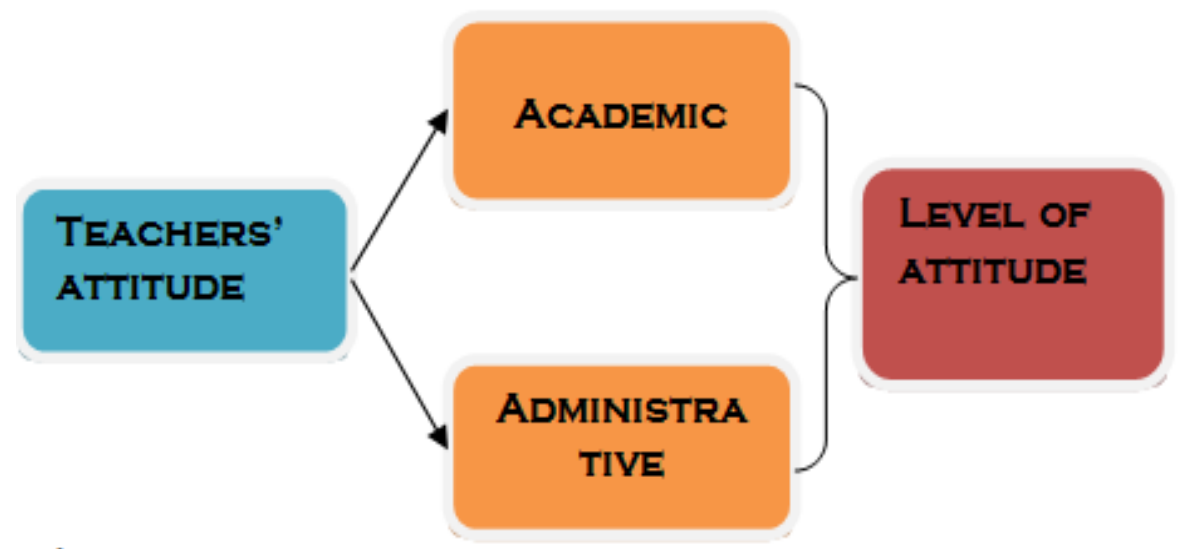

Fig 1:- Framework for the analysis of prospective teachers' attitude

\section{Objectives}

The objectives of the present paper are to test the following:

- Academic attitude of prospective teachers towards teaching profession.

- Administrative attitude of prospective teachers towards teaching profession.

\section{MATERIALS AND METHODOLOGY}

Participants: To comply with the objectives, a total of fifty B.ed students (prospective teachers) of second semester students were used as participants in this study.
Tool Used: To assess academic and administrative attitude of the prospective teachers towards teaching profession; the inventory developed by Dr. (Mrs.) Ummen Kulsum namely 'Attitude scale towards teaching' was used. The reliability of the inventory was 0.812 .

\section{Statistical Treatment}

The data collected has been analyzed, using Z- score in terms of standard deviations from the mean.

\section{RESULTS AND INTERPRETATIONS}

The first objective was to test the academic attitude of prospective teachers towards teaching profession. So, the data were examined with the help of $\mathrm{Z}$ - scores and the result is given in Table 1 .

\begin{tabular}{|c|c|c|c|c|c|c|}
\hline $\mathbf{N}$ & $\begin{array}{c}\text { Raw Score } \\
(\mathbf{x})\end{array}$ & $\begin{array}{c}\text { Mean } \\
(\mathbf{u})\end{array}$ & $\begin{array}{c}\text { S.D } \\
(\boldsymbol{\sigma})\end{array}$ & $\mathbf{Z}$ - Score & Grade & Level of attitude \\
\hline 50 & 21.75 & 6.13 & 1.23 & -0.50 & $\mathrm{D}$ & Average/Moderate Positive \\
\hline
\end{tabular}

Table 1:- Result of academic attitude of prospective teachers

From the table 1, it is marked that the raw score (x) is 21.75 , mean $(u) 6.13$, S.D $(\sigma) 1.23$. When, these values are referred to the Established Norms for Interpretation, it falls under the range of -0.50 to +0.50 to $\mathrm{Z}-$ scores, which is graded as 'D', and is interpreted at level of attitude as 'Average/Moderate Positive', in the Hierarchical Order of 'Extremely Positive (A), Highly Positive (B), Above Average Positive (C), Average/Moderate Positive (D), Below Average (E), Highly Negative $(F)$, and Extremely Negative $(G)^{\prime}$. Hence, it can be stated from the result, that the academic attitude of prospective teachers was average/moderate positive. Hence, prospective teachers need to work on their attitude towards development of academic attitude more positively.

The second objective was to test the administrative attitude of prospective teachers towards teaching profession. So, the data were examined with the help of Zscores and the result is given in Table 2. 
ISSN No:-2456-2165

\begin{tabular}{|c|c|c|c|c|c|c|}
\hline $\mathbf{N}$ & $\begin{array}{c}\text { Raw Score } \\
(\mathbf{x})\end{array}$ & $\begin{array}{c}\text { Mean } \\
(\mathbf{u})\end{array}$ & $\begin{array}{c}\text { S.D } \\
(\boldsymbol{\sigma})\end{array}$ & $\mathbf{Z}-$ Score & Grade & Level of attitude \\
\hline 50 & 17.94 & 3.4 & 0.92 & +1.19 & $\mathrm{C}$ & Above Average Positive \\
\hline
\end{tabular}

Table 2:- Result of administrative attitude of prospective teachers

From the table 2, it is marked that the raw score (x) is 17.94, mean (u) 3.4, S.D $(\sigma)$ 0.92. When, these values are referred to the Established Norms for Interpretation, it falls under the range of +0.51 to +1.25 to $\mathrm{Z}-$ scores, which is graded as ' $D$ ', and is interpreted at level of attitude as 'Above Average Positive', in the Hierarchical Order of 'Extremely Positive (A), Highly Positive (B), Above Average Positive (C), Average/Moderate Positive (D), Below Average $(E)$, Highly Negative $(F)$, and Extremely Negative $(G)$ '. Hence, it can be stated from the result, that the administrative attitude of prospective teachers was above average positive. Hence, prospective teachers need to keep on working on their attitude towards development of administrative attitude more positively.

\section{DISCUSSION}

The study revealed that academic and administrative attitude towards teaching profession was average/moderate positive, and above average positive respectively, under the hierarchical order of seven levels of attitude. This could be due to late selection of teaching as their profession. Because, it is assumed that teaching profession was not the first choice for many of the teacher trainees. As a consequence, late selection of teaching as their profession their attitude is just average and above average. However, now they want to enter into teaching profession due to high demand, easy and secure job opportunity available in the region. Whatever could be the reasons for their average/ moderate positive and above average positive attitude towards teaching profession they need to upraise their attitude towards the same. Because, as it has been stated by Bean (1996) that positive professional attitude helps teacher to develop, and has the ability to establish positive environment where each individual is able to contribute, be it a teacher, or parent, or a student. They have an adequate and absolute check on the teaching and learning environment, and monitor it productively. According to Baxter (1989) teachers with positive attitude have stable emotions and feelings. They show affection, sincerity, patience, and care while interacting with students, teachers, parents or school staff. They do not belief in segregation but collaboration. Such teachers work in cooperation and they have high positive self-esteem. Students do not hesitate to meet such a teacher as they are approachable to every individual openly. Hence, it can be stated that teachers make a positive difference in the lives of students. The positive attitudes and actions utilized by teachers ultimately can make a significant positive difference on the lives of their students.

\section{CONCLUSION}

Education is the process of facilitating learning, or the acquisition of knowledge, skills, values, beliefs, and habits. It is universally accepted truth, that education mostly takes place in the school, under the guidance of teachers. It has been found out that teacher's efficiency in handling particular topic and execution in the classroom are based on his attitude towards profession up to a large extent. So, teacher plays the most important role in imparting quality education in regular as well as in irregular situations. Therefore, it is crucial to prepare well-equipped teacher trainees and this can be obtained by providing them different trainings in the areas of psychology, sociology, assisted classroom teaching, providing them regular feedback, etc. It is also necessary to help them acquire ideas related to non-stop learning, perform their jobs enthusiastically and facilitate the development of positive attitudes. Hence, he/she has to learn all the qualities of head, hand and heart through the process when he is in his training period.

\section{REFERENCES}

[1]. Bain, K. (2004). What the Best College Teachers Do. (Document based on Bain's book of this title.), Retrieved on 31 July 2020 from http://fic.engr.utexas.edu/files. pdf.

[2]. Benjamin, A. E. W.; Sahayarani, J. \& Stanly, L. S. (2011). A study on attitude towards teaching profession and achievement in teaching competency of B.Ed. trainees. New Frontiers in Education. 44(3), 250-253.

[3]. Baxter, M. (1989). Measures to improve the effectiveness of teaching in UK schools. La Fisica Nella Scuola, Supplemento Speciale, XXII, 4.

[4]. Bozdogan, A. E.; Aydin D. \& Yildirim, K. (2007). Teachers' attitudes towards teaching profession. Kirsehir, j. Educ .8(2); 83-97.

[5]. Capa, Y. \& Cil, N. (2000). Teachers' Attitudes towards teaching profession an investigation of different variables. Hacettepe University J. Educ .., 18; 69-73.

[6]. Celikoz, ., \& Cetin, F. (2004). In: Ahmad \& Sahak (2009), op.cit. GCPI. (1981). A study of relationship of academic achievement with attitude towards teaching among teacher trainees, Allahabad.

[7]. Ghosh, S. and Bairgya, S. (2010). Attitude of secondary school teachers towards teaching profession in relation to some demographic variables, Edusearch 1(1), 55-58. 
[8]. Gnanaguru, S. A. \& Kumar, S. (2007). Attitude of under normal and overachievers towards teaching profession and their home environment. Journal of All India Association for Educational Research , 19 (3 \& 4) 36-37.

[9]. Kulsum, Umme (2014). Attitude Scale towards Teaching Profession. Agra: National Psychological Corporation.

[10]. Leite, A.F. (1994). In: Affizal Ahmad \& Rafidah Sahak. (2009). Teacher-student attachment and teachers' attitudes towards work. Journal Pendidik den Pendidikan, Jill, 24, 55-72.

[11]. Mishra, G. (1977). A study of the attitudes of teachers working in Government aided conventional Sanskrit Vidyalayas of Varanasi towards teaching profession.

[12]. Mordi, C. (1991). Factors Associated with pupil's Attitudes Towards Science in Nigerian Primary Schools. Res. Sci.Technol Educ .,9 (1); 39-41.

[13]. Naik, A. K. \& Pathy, M. K. (1997). A study of the attitudes of secondary school science teachers towards teaching of science. School Science, 35 (2), 59-62.

[14]. Osunde, A. U. \& Izevbigie, T. I. (2006). An assessment of teachers' attitude towards teaching profession in Midwestern Nigeria. Education, 126 (3), 462-467.

[15]. Rawat \& Sreevastava, R. K. (1984). Attitude of male and female teacher trainees towards teaching-a comparative study. Asian journal of Psychology and Ed ucation, 13, 54-58.

[16]. Sabriye, S. (2020). "Examining trainee teachers' attitudes towards teaching profession: Canakkale Onsekiz Mart University case", retrieved on 27 July 2020 from www.sciencedirect.com.

[17]. Theresal, L. K. \& Benjamin, A. E. W. (2011). Attitude towards teaching profession and self esteem among student-teachers. New Frontiers in Education , 44 (3), 257-260. 